\title{
How can brand equity for tourism destinations be used to preview tourists' destination choice? An overview from the top of Tower of Babel
}

\section{Como prever as escolhas dos turistas a partir do valor das marcas de destinos turísticos?Uma visão geral a partir do topo da Torre de Babel}

\author{
Francisco Dias \\ Polytechnic Institute of Leiria and CITUR - Centre of Applied Research in Tourism, \\ Santuário de Nossa Senhora dos Remédios, 2520-641 Peniche, Portugal, \\ francisco.dias@ipleiria.pt \\ Lucília Cardoso \\ CEPESE - Centro de Estudos da População, Economia e Sociedade, \\ Rua do Campo Alegre, 1021, 4169-004 Porto, Portugal, \\ lucyalves.lucilia@gmail.com
}

\begin{abstract}
:
Customer-based brand equity for tourism destinations (CBBE-TD) is a helpful construct to assess destination branding effectiveness. However, it would be even more useful if it could be integrated into a wider methodological approach articulating destination brand assessment with the destination choice process. This paper describes a new research programme - Favourite Destinations Worldwide - that includes three interrelated innovative tools: (1) the destination brand choice model that allows a better conceptualization of CBBE-TD in the context of destination choice; (2) the Tower of Babel platform, a multilingual online survey for data gathering, to assess CBBE-TD of all destinations competing in the world market; and (3) the Destination Brand Gnosis, a propriety software for qualitative data analysis, transforming the meta-data into a system for constantly evaluating brand attractiveness. Additionally, for illustrative purposes empirical data from two national samples is presented: Portuguese $(N=524)$ and Brazilian $(\mathrm{N}=955)$. Besides presenting the preferred destination brands for Brazilian and Portuguese tourists, the results confirm a basic assumption supporting this research program related to the geographic polarization of the most valued destination brands: "dream destination brands" correspond to destinations located farther from respondents' home-places, in other continents, requiring long-haul air travel, while "favourite destination brands" are predominantly destinations located nearer, in respondents' own countries or neighbouring countries.
\end{abstract}

Keywords: Brand equity, destination choice, dream destination, favourite destination.

\section{Resumo:}

O constructo "customer-based brand equity" de destinos turísticos (CBBE-TD) é útil na avaliação da eficácia das marcas de destinos turísticos. Mas seria ainda mais útil se fosse integrado numa abordagem ampla que articulasse a avaliação das marcas de destino com o processo de escolha de destinos. Este artigo descreve um novo programa de pesquisa - Favorite Destinations Worldwide - que inclui três ferramentas inovadoras inter-relacionadas: (1) o destination choice model que transpõe o CBBE-TD para o contexto da escolha de destinos; (2) a plataforma Tower of Babel, um inquérito online multilingue para avaliação do CBBE-TD de todos os destinos existentes no mercado mundial; e (3) o Destination Brand Gnosis, um software de análise de dados qualitativos que transforma meta-dados num sistema de monitorização da atratividade de marcas. Para ilustrar os propósitos desta abordagem empírica, são apresentados os resultados da amostra portuguesa $(N=524)$ e da brasileira $(N=955)$. Além de serem elencadas as marcas de destino preferidas dos brasileiros e portugueses, os resultados confirmam um pressuposto básico subjacente a este programa de investigação, que consiste na polarização geográfica das marcas de destino mais valiosas: as marcas de destino de sonho correspondem a destinos localizados longe da área de residência, noutros continentes, que exigem viagens aéreas de longo curso; já as marcas de destinos favoritos remetem para locais mais próximos, nos países de residência ou em países vizinhos.

Palavras Chave: Valor da marca, escolha de destinos, destinos de sonho, destinos favoritos.

\section{Introduction}

In the light of numerous studies conducted during the last decades, competitiveness of tourist destinations depends directly on how they are perceived by actual and potential tourists, in terms of their relative/comparative attractiveness (e.g., Javalgi, Thomas \& Rao, 1992; Driscoll, Lawson \& Niven, 1994; Botha, Crompton \& Kim 1999; Crouch \& Ritchie, 2012; Dupeyras \& MacCallum, 2013). The way a destination is perceived by tourists (particularly in terms of its relative quality, prestige and brand image) is a critical success factor in a global competition context (Kozak \& Rimmington, 1999; Woodside \&

Lysonski, 1989; Leung \& Baloglu, 2013). In tourism the most attractive destinations are the most desired and sought after by consumers, consequently, when a destination achieves the status of "favourite" among consumers, it simultaneously acquires a very important competitive advantage over competitors.

The brand image of tourist destinations is of utmost importance as tourism products are usually purchased (well) in advance before departing on holidays - by many different consumers from different countries and cultures. This specific circumstance demands an adequate understanding of cultural and socio-psychological dimensions of tourist behaviour, even 
more necessary, in particular, the role of cognition and emotions in the choice of a destination. That is to say, the role of brand equity in the consumer's decision making process. Destination image can be described as "the set of expectations and perceptions a prospective traveller has of a destination. Past experience of the destination or the companies involved (i.e., airlines, hotels, tour operators); descriptions by friends and relatives; general information; and marketing campaigns develop these expectations and perceptions which may be true or imaginary representations" (Buhalis, p. 101). However, as Buhalis (2000, p. 99) also stated, "tourists perceive the destination as a brand comprising of a collection of suppliers and services". Thus, describing destination as a brand and destination image as a core factor in destination choice, the author implicitly anticipated the contemporary conceptualization of destination image as a component of destination brand.

The relationship between both concepts - destination image and destination brand - became an accepted matter when researchers adopted the brand equity construct (Keller \& Lehmann, 2003). Brand equity is generally accepted as a critical success factor to differentiate companies, entities and service providers from their competitors. Brands with high levels of equity have outstanding performances, namely: sustained price premium, high market shares, inelastic price sensitivity, competitive cost structures and high profitability (Keller \& Lehmann, 2003; Vazquez, Belen del Rio \& Iglesias, 2002; Keller, 2016).

In fact, before travelling, each tourist (or group of tourists) considers distinct alternatives, and the likelihood of a given destination being considered as a possible choice depends on his/her knowledge and beliefs (destination awareness), and also on more subjective elements such as emotions, attitudes towards, images of destinations, previous experiences, etc. Put differently, the likelihood of a given destination being chosen depends on its relative brand equity, when compared with its competitors.

However, up to now there is no integrative approach bringing together the concepts of customer-based brand equity for tourism destinations (CBBE-TD) and destination choice set (DCS). This paper is part of a broader research programme that aims to propose a new paradigm of destination branding assessment, by integrating both brand equity for destinations and destination choice issues, and producing a destination brand choice model (DBC model). Indeed, when both constructs are considered individually they are not of much use for the tourism sector. Alternatively, if they are put together, those constructs will be very useful for assessing and monitoring destination branding effectiveness.

Furthermore, the most relevant innovation of Favourite Destinations Worldwide research programme is its consideration of the relationship between brand equity for tourism destinations and destination choice in its real context: the global tourism market. In other words, the DBC model

considers all existing destinations worldwide at the same time: through an online survey using 36 linguistic versions, where respondents from all over the world can report spontaneously by free recall what their "dream" and "favourite" destinations are, and describe them. The outputs of the project Favourite Destinations Worldwide are very useful, since they provide information that enables the assessment of destination brands' comparative performance.

Thus, the main goal of this paper is fivefold:

- To describe the construct of costumer-based brand equity for tourism destinations (CBBE-TD) as a helpful tool for assessing destination attractiveness;

- To stress the importance of CBBE-TD in the context of the destination choice;

- To propose an integrative model of destination attractiveness - the destination brand choice model (DBC model) - that associates the four components of CBBE-TD (brand name awareness, brand association, perceived quality and brand loyalty) with the stages of the destination choice flowchart;

- To present an empirical tool - the Tower of Babel multilingual survey - that will allow the gathering of data to be analysed according to the DBC model;

- To exemplify this innovative approach using data from two samples (Portuguese and Brazilian) that were processed with the proprietary software DB Gnosis.

\section{The CBBE-TD as a tool for assessing destination attractiveness}

The overall attractiveness of any destination depends on how it is represented in the tourist's mind, as a summary mix of different components of destination brand (Blain, Levy \& Ritchie, 2005; Pike 2004; Yang, Liu \& Li, 2015). These brand components are integrated under the brand equity construct.

Brand equity can be defined as "a set of brand assets and liabilities linked to a brand, its name, and symbol that add to or subtract from the value provided by a product or service to a firm and/or to that firm's customers" (Aaker, 1991: 15). However, this initial definition does not make a strict distinction between added value for the customer/consumer and added value for the brand owner. A further development of the brand equity construct leads to the conceptualization of the "customer-based brand equity" (CBBE) model (Keller, 1993, 2009).

According to Konecnik \& Gartner (2007), brand equity is the sum of factors contributing to a brand's value in the consumer's mind, and it has been used by researchers as the key concept to measure brand performance effectiveness. Briefly, the CBBETD is the value of a brand based on to what extent it has name awareness, perceived quality, strong brand associations and a high brand loyalty (Kotler \& Armstrong, 2008). These four dimensions of the CBBE-TD construct are summarized in Table 1. 
Table 1: The brand equity dimensions

\begin{tabular}{|c|c|}
\hline Dimensions & Description \\
\hline Brand awareness & $\begin{array}{l}\text { It reflects the salience of a destination brand in the tourists' mind, and it can be assessed at several levels (Aaker, } \\
\text { 1996): } \\
\text { Recognition } \\
\text { Free recall } \\
\text { Top-of-mind } \\
\text { Brand dominance (when a brand is the only one recalled) } \\
\text { Brand knowledge }\end{array}$ \\
\hline $\begin{array}{l}\text { Brand } \\
\text { associations }\end{array}$ & $\begin{array}{l}\text { It is the starting point for purchase decision and for brand loyalty (Aaker, 1991), and includes three major categories } \\
\text { (Keller, 1993): } \\
\text { Attributes are descriptive features that characterize a brand; they consist on what a tourist thinks the destination } \\
\text { brand is or has to offer and what is involved in its purchase or consumption. } \\
\text { Benefits are the personal values that consumers associate with the brand attributes (what consumers think the brand } \\
\text { can do for them). Tourists can benefit from functional and non-functional (symbolic) attributes and experiential } \\
\text { attachments. } \\
\text { Brand attitudes are tourists' overall evaluations of the destination brand and are the basis for tourists behaviour (e.g., } \\
\text { destination choice) }\end{array}$ \\
\hline Perceived quality & $\begin{array}{l}\text { It is the overall perception of customers about brilliance and quality of products or services in comparison with the } \\
\text { rivalry offering (Aaker, 1991). } \\
\text { When the intangible attributes acquire high predominance, as is the case in tourism, the quality assessment depends } \\
\text { almost exclusively on perceived quality. }\end{array}$ \\
\hline Brand loyalty & $\begin{array}{l}\text { It consists of the attachment that a customer has to a brand. } \\
\text { Loyalty includes four different levels: cognitive, affective, conative and action loyalty (Oliver, 1997, 1999; Blut, } \\
\text { Evanschitzky, Vogel \& Ahlert, 2007). } \\
\text { Cognitive loyalty occurs whenever a brand appears first in a consumer's mind and when the need to make a purchase } \\
\text { decision arises, being the consumer's first choice. It is closely linked to the highest level of awareness (top-of-mind). } \\
\text { Affective loyalty consists of a favourable attitude towards a particular destination brand, and it is an outcome of the } \\
\text { consumer's satisfaction. } \\
\text { The conative loyalty expresses the consumer's commitment with a future purchase, but without conclusive fulfilment, } \\
\text { as it is usually expressed as recommendation to friends and relatives. } \\
\text { Action loyalty: consists of the ability to overcome inertia and to achieve the repeated purchase, even if it is necessary } \\
\text { to overcome obstacles. }\end{array}$ \\
\hline
\end{tabular}

It is highly relevant the fact that all brand equity dimensions are closely related. On one hand, the top-of-mind awareness represents cognitive loyalty. If a given destination is the first to come to the consumer's mind (higher salience) it also benefits from cognitive loyalty. On the other hand, the other three forms of destination loyalty (affective, conative and action loyalty) derive directly from the brand's associations (favourable attributes, perceived benefits and attitudes).

Even though, it is important to remark that causal relationships between consumer satisfaction and repeated purchase, rarely are the common pattern in tourism behaviour, as tourist motivation is mostly driven by the search for novelty, new experiences and exploring unknown destinations. Accordingly, conative loyalty (recommendation to friends and relatives) is the most common form of loyalty towards destination brands.

\section{CBBE-TD in the context of the destination choice}

Tourism destination choice depends on brand equity within the tourism destination framework. However, in tourism research these two topics have been considered independently, so far. The existing literature on destination choice refers to specific aspects of the destination choice behaviour, such as travel motivations and destination image, or refers to general models of the destination choice decision-making process, but without connecting it with the branding issue. This article is probably the first attempt to bring together these two issues. According to the destination choice theory, consumers initially categorize in their minds the alternatives of which they are aware into a number of sets
(Woodside \& Lysonski, 1989; Um \& Crompton, 1990; Oppewall, Huybers \& Crouch, 2015). A careful consideration of these mental sets becomes very pertinent for many areas of destination choice behaviour, including the destination branding assessment issue.

The main assumption of the traditional destination choice set approach is that tourism consumers start out the decision process by making a broad selection of (acceptable) alternatives, among the many available alternatives. This activity continues until they have gathered sufficient information, after which they spend time inspecting closely the alternatives selected in their consideration set. After making their final trade-offs, consumers choose what alternative to purchase (Woodside \& Lysonski, 1989; Um \& Crompton, 1990).

Decrop (2010) analysed the formation and evolution of the tourist destination choice through a longitudinal approach. The proposed destination choice set model considers four stages, starting from the consideration stage, evolving through evaluation, and constraints stages and finally concluding into the destination choice (Figure 1). Decrop's destination choice set model is based on the theoretical foundation that all choice sets are under the dynamic influence of a continuous constraint/opportunity evaluation. An interesting Decrop's (2010) contribution to the existing literature of destination choice is that, due to situational constraints, consumers are lead to split the evoked set into three distinct categories: dream set, unavailable set and available set. 
Figure 1: Destination choice set - Decrop's model

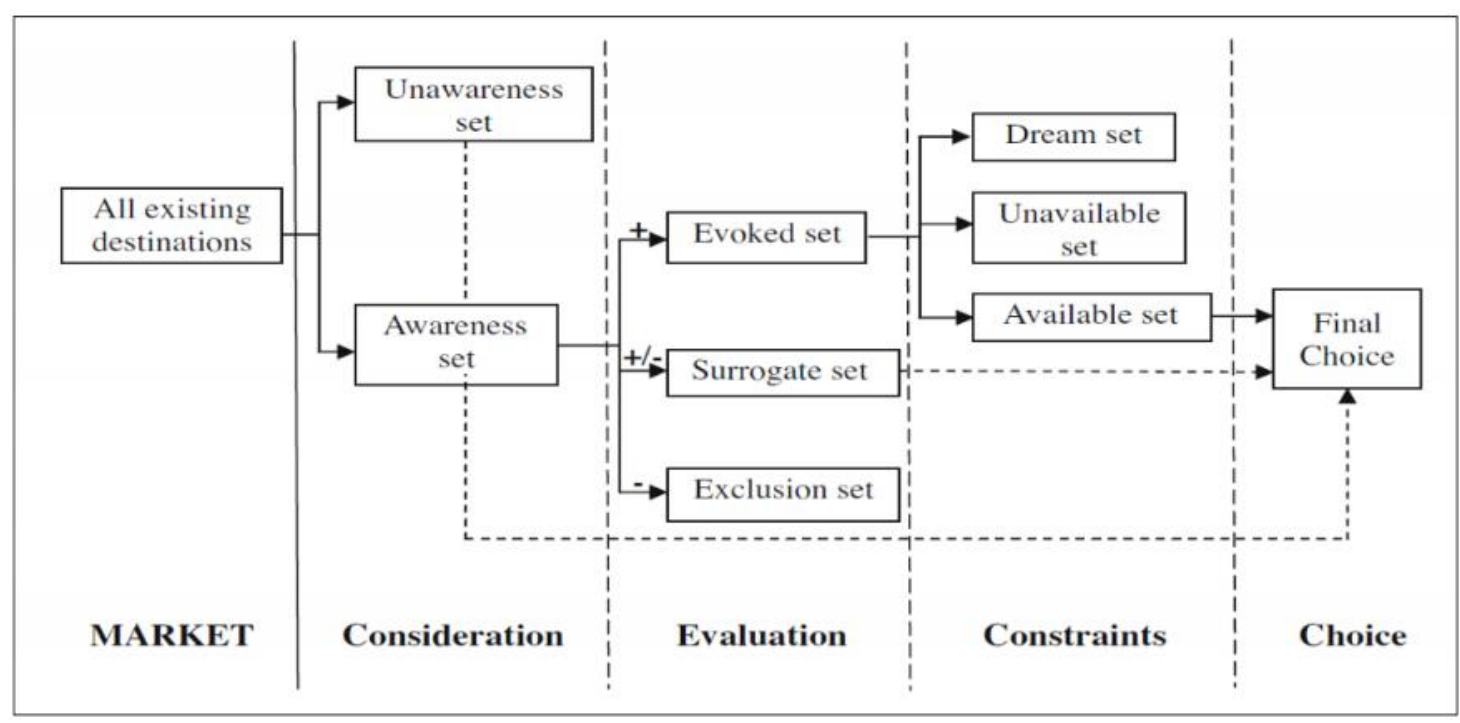

Source: Adapted from Decrop (2010).

Decrop's model takes advantage over the classical destination choice models (Woodside \& Lysonski, 1989; Um \& Crompton, $1990)$ as it presents a logical sequence of a decisional funnel that evolves along four cognitive tasks: consideration, evaluation, coping with constraints and choice.

Just destinations included in the awareness set are subsequently submitted to an initial screening, leading to their distribution into three categories: (1) "exclusion set", categorizing destinations that do not meet the requirements of a given choice; (2) "surrogate set", representing destinations that in certain circumstances do not meet the choice criteria, but in others could be selected; (3) "evoked set" encompassing destinations that meet the minimum requirements for the choice. The following stage happens when the individual takes into account the various constraints that prevent his/her free choice. The constraints can be of different scope: financial, time, family, political (visa, for example) or others. Only destinations that are not limited by any kind of constraints ("available set") can reach the stage of final choice.

\section{CBBE-TD and destination choice set: the destination brand choice model (DBC model)}

Being destination choice highly permeable to the influence of destination branding, the CBBE-TD construct acquires an utmost relevance for understanding the destination choice process. Awareness is the first dimension of CBBE-TD and also stands out as the first step of destination choice (Figure 1 ), as a sine qua non condition for a given destination be to be taken into account in a future decision. Although there are many thousands of destinations in the world, only a few fall under the "awareness set", in other words, gain "pole position" to be considered in a subsequent choice.

Furthermore, the categorization of a destination in one of three alternative sets (evoked, surrogate or exclusion set) is based on the brand's associations (or brand image) and perceived quality of destinations. Evoked set incorporates just the destinations with higher performance in terms of brand association and perceived quality. Destinations that generate in the tourist's mind undesirable associations or negative brand image fall immediately into the exclusion set, while destinations generating a moderate impression in terms of brand association and perceive quality fall into the surrogate set.

The Decrop's (2010) model brings the advantage of highlighting the category of "dream destinations". Although this concept has not been receiving special attention from tourism brand researchers, tourist imaginary and dreaming with exotic places has been for a long time a key concept for the anthropological approach of tourism behaviour, and the source of the motivational processes in tourism studies, including the "push/pull factors" of motivations.

Although the aforementioned model seems adequate to describe a single destination choice, it fails when it does not consider the effect of previous visits in a subsequent choice. Aiming to surpass this limitation, and to integrate the four components of CBBE-TD into a more dynamic destination choice flowchart, this paper proposes a new conceptual model - the destination brand choice model (DBC model) - that stands as the basic framework of the main research programme (Figure 2). 
Figure 2: The destination brand choice model (DBC model)

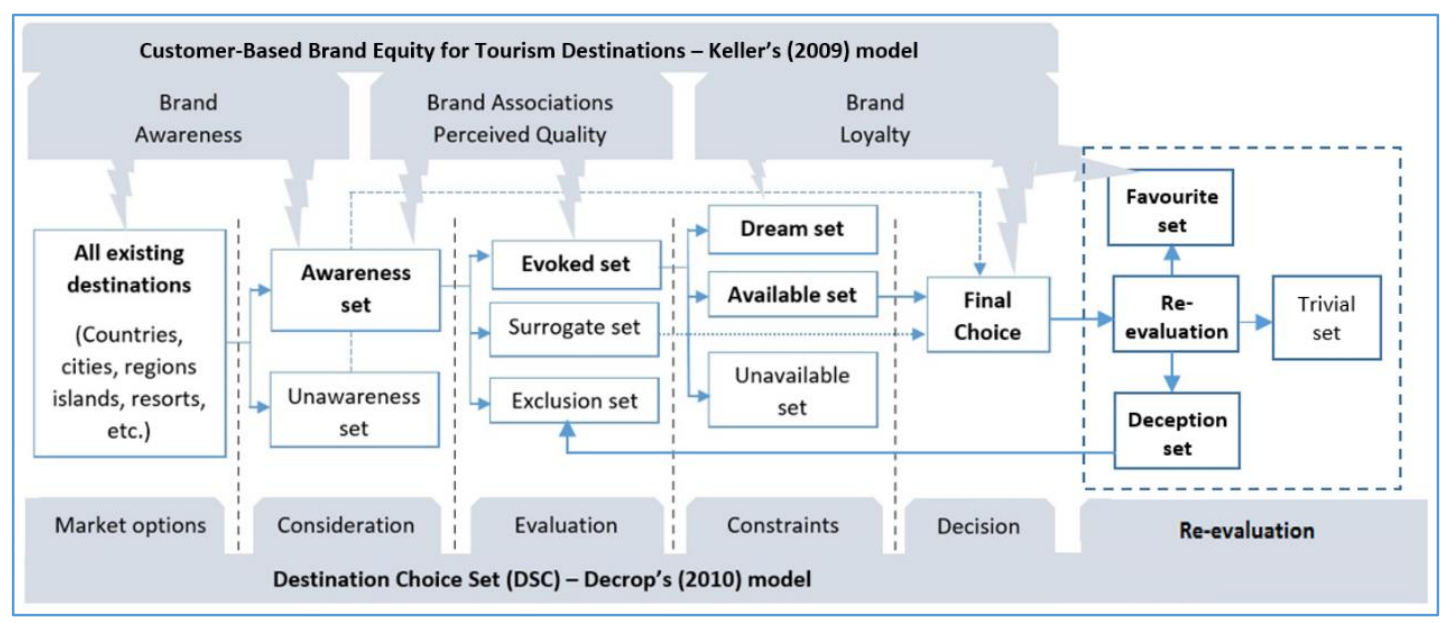

Source: Authors.

Destination brand loyalty depends logically on previous experiences of visitors and concomitantly on previous choices. After visiting a destination, tourists re-evaluate their previous choices and, depending on how they assess their on-site experience, the visited destination can be re-categorized in three different ways: i) as a destination deserving to be recommended or visited again in future, here designated as "favourite set" (the category for destinations related to memorable experiences and deserving the loyalty of tourists); ii) as a destination that doesn't impress positively or negatively the visitor, here denominated "trivial set" (to group those destinations that were not remembered in a positive or a negative way); iii) as a destination that leaves a negative impression and a bad memory, which the authors propose to be the "deception set" category.

The separation of most valued destination brands into two distinct categories - "dream" and "favourite"- reflects the main argument of this article and its authors' understanding of the subjective dynamics of consumer behaviour in tourism: dream destinations emerge in the tourists minds as the outcome of tourist imaginary and they express the ideal preferences of consumers, while favourite destinations correspond to those places that have already been visited and have aroused positive emotions on tourists, and still remain in their minds as memorable experiences. Both categories express distinct meanings of brand loyalty: while dream destinations embrace cognitive loyalty, favourite destination brands include conative loyalty and, in some cases, action loyalty.

The intrinsic merit of DBC model is related to the following advantages:

1) It explains how destination brands progress along the five stages of the destination choice flowchart, from the consideration stage to the re-evaluation stage;

2) It brings together two distinct but complementary traditions in tourism research (destination branding and destination choice), since both constructs cover the same phenomenological domain and address the same theoretical and practical concerns: the destination brand attractiveness analysis.
3) It enables the correlation of distinct forms of destination brand loyalty (cognitive, affective, conative and action) with tourist behaviour, contrasting two distinct concepts: dream destinations and favourite destinations.

4) It stresses the importance of studying CBBE-TD in the destination choice context; meaning that CBBE-TD acquires higher relevance as a monitoring tool for comparative assessment of branding effectiveness among competing destinations.

\section{A new methodological tool to assess brand equity for destinations}

\subsection{Basic assumptions}

Besides the proposition of a destination brand choice model, a new methodological tool that will make possible a comparative assessment of many destinations, is being developed. This new methodology permits to pave a pathway into a complex research domain, in order to address the following question: what destinations achieve the status of favourite destination brands and in which circumstances?

The rational underlying this new methodology consists on the following basic assumptions:

a) Tourism destinations are amalgams of tourism products offering an integrated experience to consumers (Buhalis, 2000). Therefore, the key concept is the tourist experience.

b) CBBE-TD is necessarily about experiences (anticipated or remembered) associated to a certain location.

c) Destination marketers cannot directly deliver memorable tourism experiences because such experiences are highly idiosyncratic (Tung \& Ritchie, 2011). Indeed, tourism experiences are psychological phenomena, based in and originating from the individual tourist (Larsen, 2007)

d) From these two previous assertions, one can deduce the following consequences:

- Memorable experiences are constructed by travellers on their individual assessment of subjective experiences (Kim, 2010). Those places people associate to their memorable experiences will be called "favourite destinations". 
- Memorable experiences can be anticipated or dreamed by tourists, and related with destinations they never visited before. The tourist imaginary operates with existing information to generate "dream destination".

e) CBBE-TD is a suitable tool to assess destination brand effectiveness of both already visited places (countries, cities, and regions) and not yet visited places, but desirable to be visited.

f) Countries, regions and cities from all over the world are competing in the global market to attract tourists (all of them try to achieve brand equity in people's minds). Against this background of high strong competition, to assess CBBE-TD for a specific tourism destination without comparing it with other competitors will be useless. CBBE-TD has to be considered a comparative measure in a continuous assessment process.

g) The free recall technique is the appropriated methodological option to be informed about destination awareness. Furthermore, the top-of-mind data, provided by free recall, is a useful indicator in the assessment of two forms of loyalty: cognitive and conative.

\subsection{The "Tower of Babel" multilingual online survey}

The "Tower of Babel" project aims to operationalize the above ideas referred to and, at the same time, to pave the way for future researches in this domain, hence, it pursuits a long term goal. Furthermore, it is not anchored on a consolidated model, but on a set of core intuitions based on empirical evidence, and on critical reflection about the scientific research domain in which it is included, what points out the innovative characteristics of this project.

The "Tower of Babel" project adopts the perspective of the "grounded theory" as its basic methodological postulate (Strauss \& Corbin, 1998; Charmaz, 2014). Therefore, the starting point was the collecting of qualitative data at a worldwide level, through an online multilingual survey, using free recall technics.

The dream destination variable was operationalized with the following two questions:

1. "Bearing in mind all tourism destinations existing all over the world, please indicate your dream destination in general. "

2. "Describe the specified destination that you have just mentioned using three words. "

Concerning data gathering related to favourite destinations, the questionnaire included a three step approach:

- Firstly, each respondent should indicate what forms of tourism he/she usually prefers, choosing one or more options from a list of 15 tourism products, namely: seaside tourism, cultural tourism, ecotourism or nature tourism, wellness tourism, rural tourism, gastronomic tourism, city tourism, mountain tourism, sport tourism, creative tourism, religious tourism, shopping tourism, cruise tourism, golf tourism, and business tourism.

- Then, he/she was invited to indicate a favourite destination related to each tourism product he/she has chosen in the previous question;

- Finally, respondents were invited to describe the selected destination by using three words.
It is important to highlight that the questionnaire does not restrict the choice of any particular geographic category or administrative boundary, such as country, city, region, island, etc. to avoid any influence on the respondents' free recall of destinations.

The multilingual online survey, as well as information about the project and the research network are available at "Favourite Destinations" website http://favouritedestinations.com/en/.

Data collection started on April 2015 with the active support of 35 team-mates in a collaborative network, mostly of them qualified researchers from 30 research centres and universities from Europe, Asia and America. Each partner was responsible for carrying out the collection of data in his/her own native language, totalizing 36 languages, namely 25 European languages (English, Spanish, German, French, Portuguese, Russian, Turkish, Italian, Polish, Dutch, Hungary, Danish, Czech, Slovak, Swedish, Catalan, Norwegian, Greek, Romanian, Bulgarian, Croatian, Lithuanian, Latvian, Albanian and Armenian) and 11 Asian languages (Traditional Chinese, Simplified Chinese, Arabic, Japanese, Korean, Indonesian, Hindi, Thai, Marathi, Farsi and Nepali).

According to the grounded theory methodology, a set of systematic procedures for data analysis was defined to integrate data into broader frameworks or theories, namely those categories (concepts) that present a systematic view of the phenomena, especially, the relationship between variables (Strauss \& Corbin, 1998, p. 22). In short, the theoretical model is not the departing point of this project but its final outcome.

Besides assessing the attractiveness of destination brands, this projects aims to shed light on issues not yet explored, such as: "What are the core attributes of a dream destination?"; or "Are the attributes of dream destinations invariant for different cultures or, inversely, are they culture-specific?" The same kind of inquiry can be addressed to favourite destinations related to specific tourism products (i.e., seaside tourism destinations, cultural tourism destinations, city tourism destinations, etc.). In brief, are there common characteristics that one can assign to dream destinations and to favourite destinations, and if so, which are they?

\subsection{Gathering knowledge from a mega-data: The DB Gnosis}

The use of free recall technics and the analysis of semantic data (names of destinations and its attributes) are very complex tasks. Its complexity is increased due to the multiplicity of languages used on the surveys and due to the qualitative mega-data generated by such a huge project. To transform the source data into useful knowledge for scientific and practical purposes, a smart and planned management of research outputs is required.

Aiming to succeed in this complex and demanding task, the project team is composed of a highly trained and experienced IT expert, who developed a brand new proprietary software, named "Destination Brand Gnosis" (in short "DB Gnosis"). This software was used for translating to English all output files from other languages, for processing the data and presenting the results. All results from the next section were processed automatically by DB Gnosis. 


\section{Dream destinations and favourite destinations of Portuguese and Brazilian tourists}

The empirical data presented below is just a small part of a huge amount of information that was collected with the Tower of Babel multilingual online survey, and represents only the results obtained from the Portuguese section of the questionnaire.

It is noteworthy to mention that the two samples are not statistically representative of both countries population, Brazil and Portugal, although both sample sizes are large enough ( $\mathrm{N}$ $=1479$ ) to offer the possibility of observing interesting relationships between them.
Most of Brazilian respondents $(\mathrm{N}=955)$ live in the Southern states of Brazil, mainly in Rio Grande do Sul (70.1\%). In turn, the Portuguese sample $(N=524)$ is concentrated mostly in the Centre and Northern regions of Portugal. In relation to all other characteristics, both samples present a very similar pattern: predominance of females (61.8\% in both samples), prevalence of respondents under 45 years old $(85 \%$ of Brazilians and $72.9 \%$ of Portuguese), most of respondents (57.4\% of Brazilians and $56.7 \%$ of Portuguese) go on holidays for 11 to 25 days per year, and finally, only a small percentage of respondents (4.6\% of Brazilians and $6.5 \%$ of Portuguese) travels abroad frequently for professional reasons (Table 2 ).

Table 2: Socio-demographic characteristics of respondents

\begin{tabular}{|c|c|c|c|c|c|}
\hline \multicolumn{3}{|c|}{ Brazilian sample ( $\mathrm{N}=955)$} & \multicolumn{3}{|c|}{ Portuguese sample $(\mathrm{N}=524)$} \\
\hline Residence & $\mathrm{N}$ & $\%$ & & $\mathrm{~N}$ & $\%$ \\
\hline Rio Grande do Sul State & 669 & 70,1 & Centre of Portugal & 255 & 48,1 \\
\hline Minas Gerais State & 94 & 9,8 & North of Portugal & 117 & 22,1 \\
\hline Rio de Janeiro State & 66 & 6,9 & Lisbon and Tagus Valley & 108 & 20,4 \\
\hline São Paulo State & 35 & 3,7 & Alentejo & 24 & 4,5 \\
\hline Santa Catarina State & 24 & 2,5 & Algarve & 15 & 2,8 \\
\hline Other states & 66 & 6,9 & Azores and Madeira & 11 & 2,1 \\
\hline \multicolumn{6}{|l|}{ Gender } \\
\hline Female & 590 & 61,8 & Female & 324 & 61,8 \\
\hline Male & 365 & 38,2 & Male & 200 & 38,2 \\
\hline \multicolumn{6}{|l|}{ Age } \\
\hline From 17 to 25 years old & 315 & 33,0 & From 17 to 25 years old & 134 & 25,6 \\
\hline From 26 to 35 years old & 346 & 36,2 & From 26 to 35 years old & 109 & 20,8 \\
\hline From 36 to 45 years old & 151 & 15,8 & From 36 to 45 years old & 139 & 26,5 \\
\hline From 46 to 55 years old & 94 & 9,8 & From 46 to 55 years old & 95 & 18,1 \\
\hline More than 55 years old & 49 & 5,1 & More than 55 years old & 47 & 9,0 \\
\hline Mean & 32,3 & & Mean & 37,25 & \\
\hline \multicolumn{6}{|c|}{ Travelling abroad for professional reasons } \\
\hline Never & 463 & 48,5 & Never & 215 & 41,0 \\
\hline Sometimes & 280 & 29,3 & Sometimes & 155 & 29,6 \\
\hline Not So Frequently & 168 & 17,6 & Not So Frequently & 120 & 22,9 \\
\hline Frequently & 30 & 3,1 & Frequently & 25 & 4,8 \\
\hline Very Frequently & 14 & 1,5 & Very Frequently & 9 & 1,7 \\
\hline \multicolumn{6}{|c|}{ Length of holidays (away from home) } \\
\hline Less than 6 days & 127 & 13,3 & Less than 6 days & 84 & 16,0 \\
\hline From 6 to 10 days & 143 & 15,0 & From 6 to 10 days & 93 & 17,7 \\
\hline From 11 to 15 days & 357 & 37,4 & From 11 to 15 days & 163 & 31,1 \\
\hline From 16 to 25 days & 191 & 20,0 & From 16 to 25 days & 134 & 25,6 \\
\hline More than 25 days & 137 & 14,3 & More than 25 days & 50 & 9,5 \\
\hline
\end{tabular}

Source: Authors. 


\section{Results}

The results presented below were obtained by free recall, as topof-mind destinations, and they are good indicators of high levels of brand awareness, one of the most important components of CBBE-TD. Figures 3 and 4 show the top 20 dream destination brands for Brazilian and Portuguese respondents. Both samples show evidence of identical response patterns: dream destinations correspond to place brands located far away from respondents' home countries.

Figure 3: Top 20 dream destination brands (Brazilian sample)

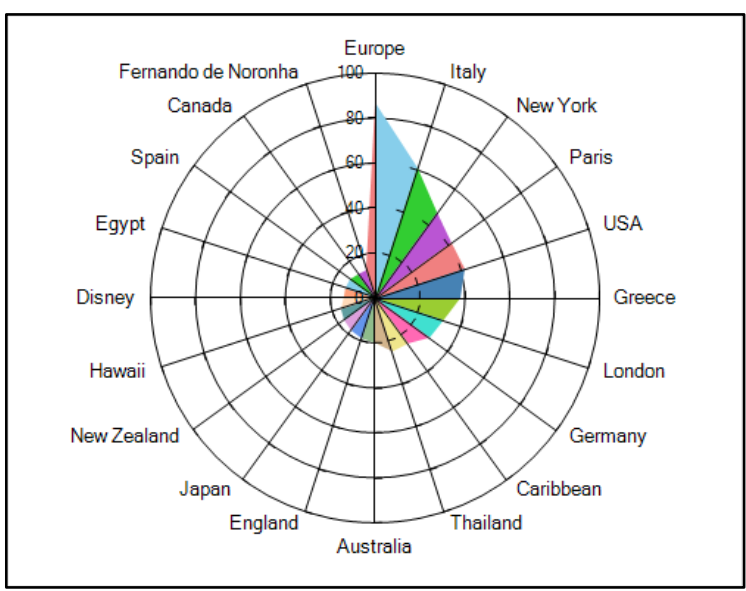

Figure 4: Top 20 dream destination brands (Portuguese sample)

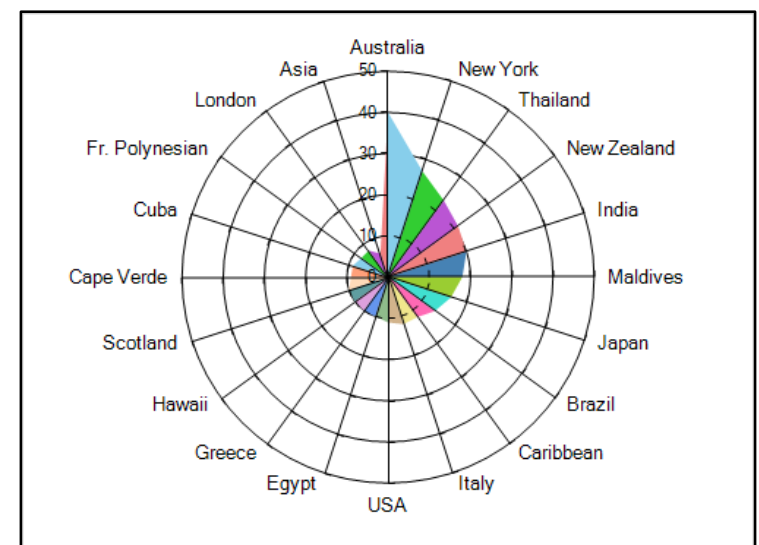

Concerning the Brazilian ranking (Figure 3), the first 19 dream destinations of the top 20 are not located in South America. Together with New York and USA, some European destinations are the most attractive brands for Brazilians, being Europe, Italy, Paris, Greece, London and Germany the most referred dream destinations (Fernando de Noronha appears in last place). Figure 4 shows a similar phenomenon with the Portuguese respondents: the top 20 dream destination brands are mainly located out of Europe, with Australia, New York, Thailand, New Zealand, India, Maldives, Japan and Brazil at the top preferences.

It is relevant to refer that in both rankings there is a mixture of geographic scales. Although country brands correspond to the most frequent geographic category, both lists also include some famous city brands (New York, Paris, and London), a multinational brand (Caribbean), a corporate brand (Disney), and sub-national brands (Hawaii, England, Scotland, French Polynesia and Fernando de Noronha).

São Paulo is the most "favourite destination" for Brazilian respondents, as it stands at the top of the top 20 list (Figure 5). Other national place brands are also well ranked (namely: Florianópolis, Gramado, Rio de Janeiro, Santa Catarina and Serra Gaúcha, Northeast and Fernando de Noronha), together with famous international brands: New York, Paris, Italy, London, USA, Miami and Buenos Aires. Portugal also belongs to the top 20 ranking of favourite destinations, but is only second to last. A similar pattern can be identified in the top 20 favourite destination brands for Portuguese respondents (Figure 6), with domestic destinations (Algarve, Portugal, Alentejo, Lisbon, Gerês, Porto, Douro and Azores) alternated between international - mostly European famous brands (London, Paris, Italy, Brazil, Barcelona, New York, Caribbean, Spain, Madrid).

Figure 5: Top 20 favourite destination brands (Brazilian sample)

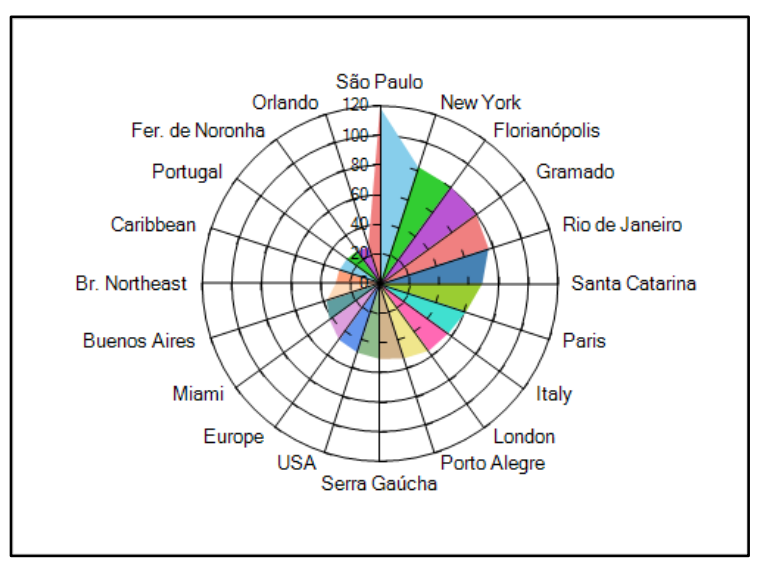

Figure 6: Top 20 favourite destination brands (Portuguese sample)

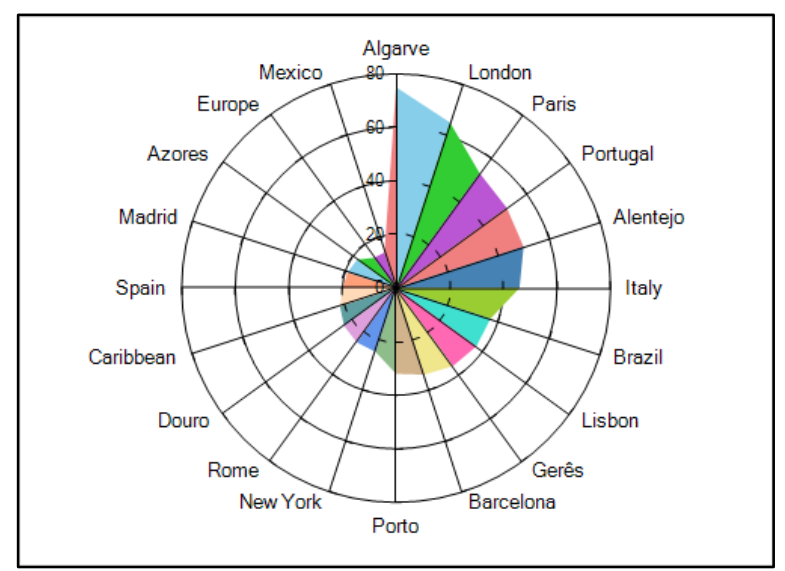

The comparison between favourite and dream destinations, in both samples, bears the following conclusions:

1) Favourite destination brands are related to domestic and intracontinental tourism, while dream destination brands are related to intercontinental tourism.

2) Although the regional (or sub-national) brands' category is very scarce when referring to dream destinations, this category 
is very popular when considering favourite destinations: Algarve, Alentejo, Gerês, Douro and Azores, for Portuguese respondents; Santa Catarina, Serra Gaúcha, Brazilian Northeast and Fernando de Noronha, for Brazilians.

The most repeated attributes respondents have associated by free recall to São Paulo (Figure 7) and Algarve (Figure 8) are indicated below. Brand image is built by the brand's associations altogether, representing an important component of CBBE and all destinations are worthy of analysis. Nevertheless, we present just the outputs for São Paulo in Brazil and Algarve in Portugal, depicting the most popular destination brand associations, delivered by the DS Gnosis software.

Figure 7: Attributes associated to São Paulo (top 1 destination in the Brazilian sample)

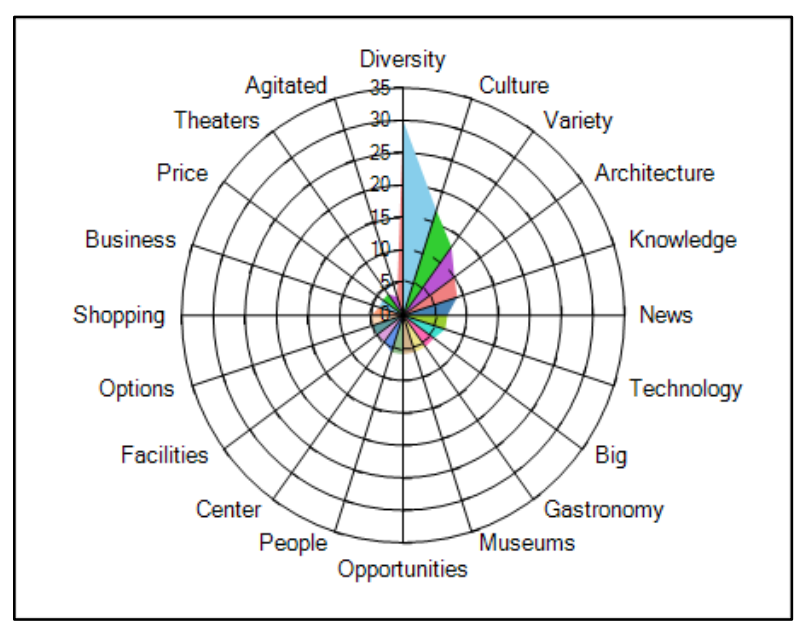

Figure 8: Attributes associated to Algarve (top 1 destination in the Portuguese sample)

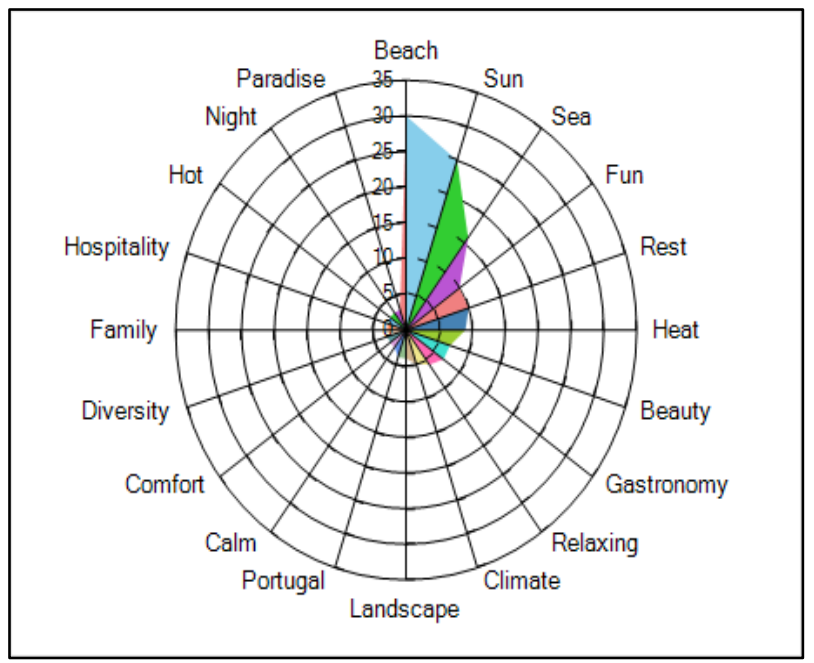

Figures 9 and 10 summarize the answers from Brazilian and Portuguese respondents about their preferences in terms of tourism products. Interestingly, the results obtained from both samples prove to be very similar. The only difference that stands out is the "shopping tourism" product, which performs better for Brazilians than for Portuguese respondents. In both samples, "seaside tourism" and "cultural tourism" scored the highest preference.
Figure 9: Ranking of products consumed by respondents (Brazilian sample)

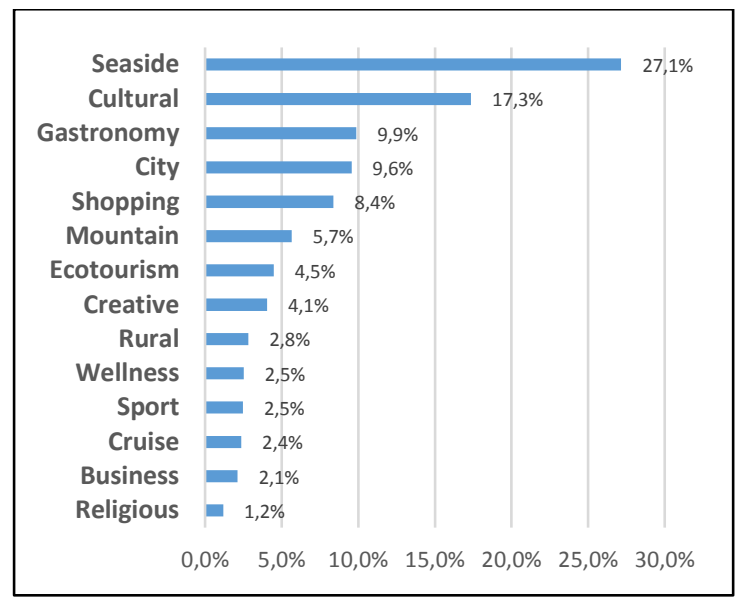

Figure 10: Ranking of products consumed by respondents (Portuguese sample)

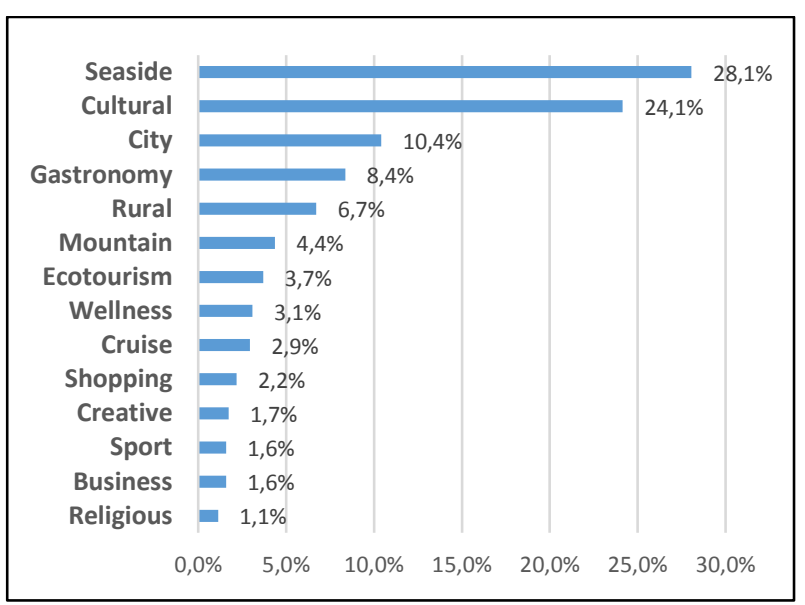

Figures 11 and 12 depict the most favourite destinations for Brazilian and Portuguese respondents when considering seaside holidays. In the case of Brazilians, all favourite seaside tourism destinations are national, except for Cancun. The top positions are filled by Florianópolis, Santa Catarina, Rio de Janeiro and Northeast. In turn, Portuguese respondents present a more international preference pattern, just with Algarve standing out from the remaining favourite destinations.

Figure 11: The top 10 destinations brands related to seaside tourism (Brazilian sample)

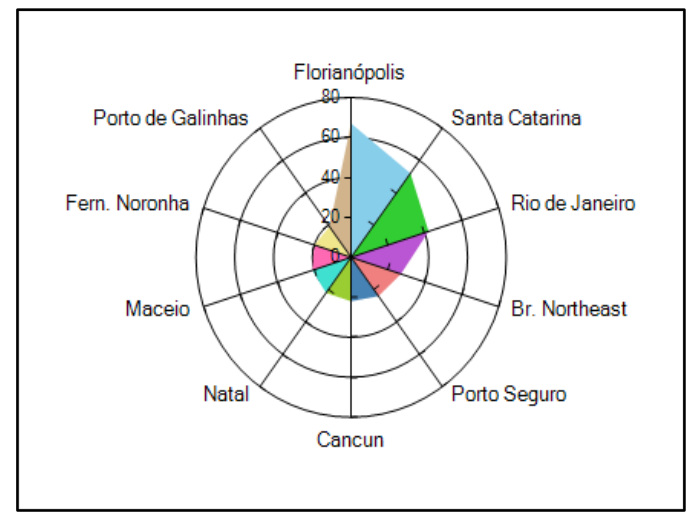


Figure 12: The top 10 destinations brands related to seaside tourism (Portuguese sample)

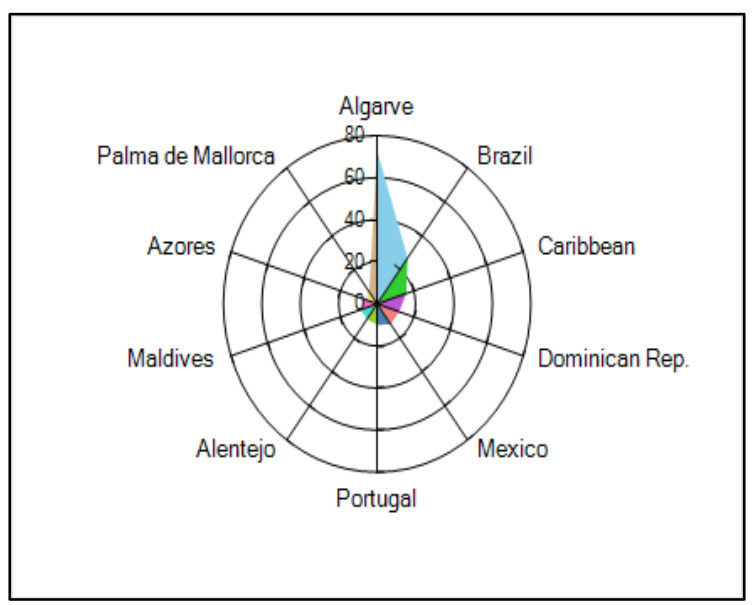

Figures 13 and 14 show the most often evoked destination brands related to cultural tourism. Aside very well-known domestic destinations (such as São Paulo, Porto Alegre and Rio de Janeiro, for Brazilians; and Lisbon and Porto, for Portuguese respondents), some famous European cities brands like Paris, London, Rome, Barcelona, Florence, Prague and New York are the most valuable destination brands for cultural tourism, along with the umbrella brand "Europe".

Figure 13: The top 10 destinations brands related to cultural tourism (Brazilian sample)

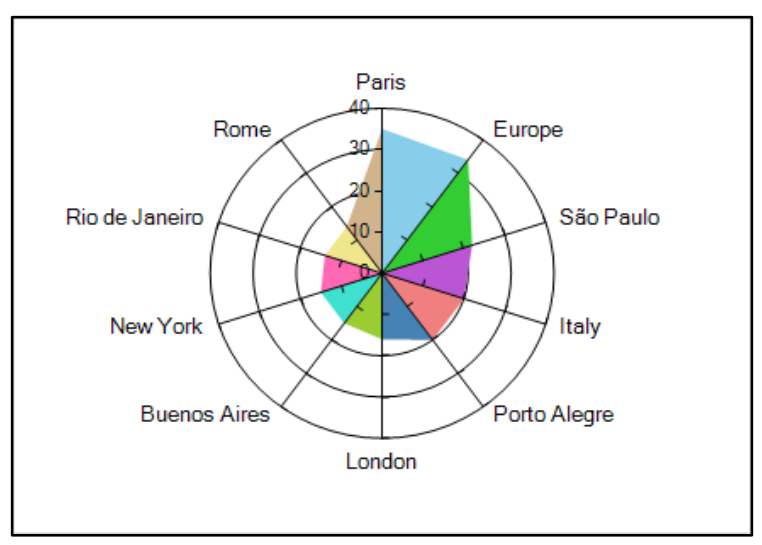

Figure 14: The top 10 destinations brands related to cultural tourism (Portuguese sample)

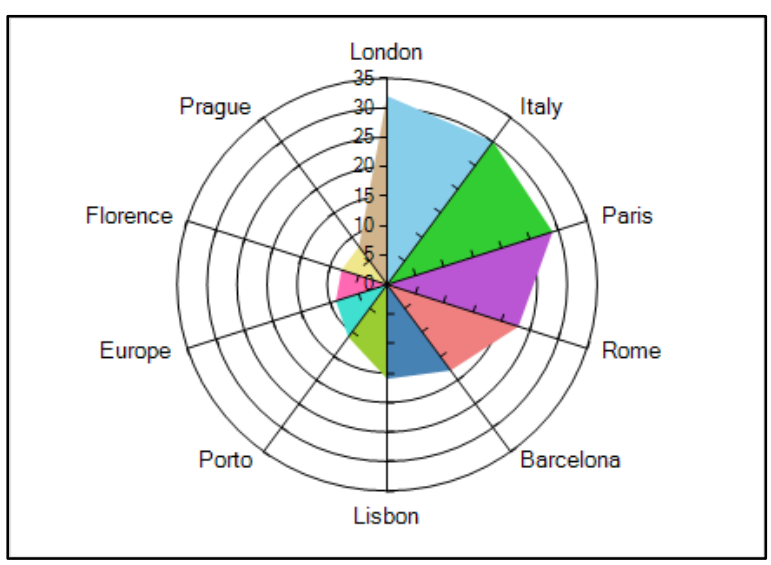

Finally, when comparing the geographic scale of the top two tourist products (seaside tourism and cultural tourism) two very different patterns are found: seaside tourism is related to destination brands which refer to regions rather than countries; as for cultural tourism, the preference goes for city brands referring to well-known cities in the world.

\section{Conclusions}

The Favourite Destinations Worldwide programme is intended to pave a new pathway in the study of destination attractiveness, overcoming the conventional approach, which consists on assessing one particular destination, on demand, or sometimes comparing it with other destinations.

In this new approach, destinations are not considered a priori because brand awareness is one intrinsic component of CBBETD. This newly-come survey consists of open-ended questions that ensure a spontaneous inform by respondents, by free recalling the destinations in their minds. This is the only reliable way top-of-mind brand awareness of tourism destinations can be measured. To assure a higher degree of liability, all answers are provided in the respondents' native language, through a multilingual online survey, with a managed hosting web service.

Accordingly, this new methodology allows the researcher to analyse CBBE-TD in a large comparative context. As respondents refer to destinations which are really meaningful for them, the questionnaire itself represents a simulation of the destination choice output. Indeed, the proposition of a new integrative approach using the DBC model stresses the importance of assessing branding effectiveness among competing destinations throughout the destination choice process.

Moreover, the DBC model highlights the heuristic value of two kinds of destination brands categories: dream destinations and favourite destinations. The former is rooted in the tourist imaginary and conveys the idea of a future destination choice; the latter is deep-rooted in the respondents' memory and is related to memorable tourist experiences. Both these categories - dream and favourite destinations - have strong brand equity. In other words, dream destinations and favourite destinations have high (top-of-mind) brand awareness, rich and positive brand associations (favourable brand image), high perceived quality and strong brand loyalty.

Furthermore, when comparing both concepts dream destination brands are located farther from respondents' home, in other continents, requiring long-haul air travel, while favourite destination brands are predominantly located nearer, in the respondents' own countries or neighbouring countries. The empirical data analysis of the Portuguese and Brazilian samples has confirmed this phenomenon of geographic polarization with the most valued destination brands.

The findings about dream and favourite destinations' geographic polarization are in accordance with Decrop's (2010) and DBC models, in what concerns the inverse proportionality of the purchasing power parity between countries, as overall revenue is one of the most important constraints on the destination choice process. 
Finally, empirical data bring on to the conclusion that strong destination brands (at the top ranking) do not necessarily get top positions at the place brand hierarchy, as, for example, brand Italy is considered stronger than Rome, but brands like Paris and London take advantage over France and UK, respectively.

\section{Some disadvantages of the Tower of Babel online survey}

The Tower of Babel online survey intends to assess destination attractiveness at a worldwide scale. The survey is carried out by a tourism research network comprising of 36 countries that helped with the translation of the questionnaires and the data collecting process. This networking approach allows a largescale coverage in the world but, at the same time, presents some disadvantages, namely:

- The quality control of data gathering is restricted to the confirmation of the computers' IP addresses used to answer the survey;

- The uniformity of procedures for all network members, during data collecting, is almost impossible to achieve.

- There is no control over respondents' motivations, neither over veracity of the information provided.

Although these disadvantages cannot be ignored, the advantages outweigh the limitations, when dealing with big data gathering requirements to create a tool for continuous assessment of destinations' attractiveness. Besides, this new methodology is unique, as it can produce updated outputs of destinations' CBBE of any place in the world, information of utmost importance for public and private stakeholders in tourism.

\section{References}

Aaker, D. A. (1991). Managing brand equity. New York: The Free Press. Aaker, D. A. (1996). Building strong brands. New York: The Free Press. Blain, C., Levy, S. E., \& Ritchie, R. B. (2005). Destination branding: insights and practices from destination management organizations. Journal of Travel Research, 43, 328-338.

Blut, M., Evanschitzky, H., Vogel, V., \& Ahlert, D. (2007). Switching Barriers in the Four-Stage Loyalty Model. Advances in Consumer Research Volume, 34, 726-734.

Botha, C., Crompton, J. L., \& Kim, S. (1999). Developing a Revised Competitive Position for Sun/Lost City, South Africa. Journal of Travel Research, 37 (3), 341-352.

Buhalis, D. (2000). Marketing the competitive destination of the future. Tourism Management, 21, 97-116.

Charmaz, K. (2014). Constructing grounded theory, 2nd Edition. Sage, London.

Crouch, G. I., \& Ritchie, J. R. B. (2012). Competitiveness and Tourism, Vol. I. Edward Elgar Publishing, Northampton.

Decrop, A. (2010). Destination choice sets: an inductive longitudinal approach. Annals of Tourism Research, 37(1), 93-115.

Driscoll, A., Lawson, R., \& Niven, B. (1994). Measuring Tourists' Destination Perceptions. Annals of Tourism Research, 21(3), 499-51.

Dupeyras, A., \& MacCallum, N. (2013). Indicators for Measuring Competitiveness in Tourism: A Guidance Document, OECD Tourism Papers, No. 2013/02, OECD Publishing, Paris.
Javalgi, R. G., Thomas, E. G., \& Rao, S. R. (1992). US Pleasure Travellers' Perceptions of Selected European Destinations. European Journal of Marketing, 26 (7), 45-64.

Keller, K. L. (1993). Conceptualizing, measuring, and managing customer-based brand equity. Journal of Marketing, 57, 1-22.

Keller, K. L. (2008). Strategic Brand Management: Building, Measuring and Managing Brand Equity, 3rd ed., Ney Jersey: Pearson Education.

Keller, K. L. (2009). Building strong brands in a modern marketing communications environment. Journal of Marketing Communications, 15(2-3), 139-155.

Keller, K. L. (2016). Reflections on customer-based brand equity: perspectives, progress, and priorities. AMS Review, 6 (1), 1-16.

Keller, K. L., \& Lehmann, D. R. (2003). The brand value chain: Optimizing strategic and financial brand performance. Marketing Management (May/June), 26-31.

Kim, J. H. (2010). Determining the factors affecting the memorable nature of travel experiences. Journal of Travel \& Tourism Marketing, 27(8), 780-796.

Konecnik, M., \& Gartner, W. C. (2007). Customer-based Brand Equity for a Destination. Annals of Tourism Research, 34(2), 400-421.

Kotler, P. \& Armstrong, G. (2008). Principles of Marketing. Upper Saddle River, NJ: Prentice Hall.

Kozak, M., \& Rimmington, M. (1999). Measuring Tourist Destination Competitiveness: Conceptual Considerations and Empirical Findings. Hospitality Management, 18(3), 273-283.

Larsen, S. (2007). Aspects of a psychology of the tourist experience. Scandinavian Journal of Hospitality and Tourism, 7(1), 7- 18.

Leung, X. Y; \& Baloglu, S. (2013). Tourism Competitiveness of Asia Pacific Destinations. Tourism Analysis, 18 (4), 371-384.

Oliver, R. L. (1997). Satisfaction: A behavioural perspective of the consumer. New York: Irvin/McGraw-Hill.

Oliver, R. L. (1999). Whence Consumer Loyalty? Journal of Marketing, 63 (Special Issue), 33-44.

Oppewall, H; Huybers, T; \& Crouch, G. I. (2015). Tourist destination and experience choice: A choice experimental analysis of decision sequence effects. Tourism Management, 48, 467-476.

Pike, S. (2004). Destination marketing organizations. Advances in tourism research series. New York: Elsevier.

Strauss, A., \& Corbin, J. (1998). Basics of Qualitative Research: Techniques and Procedures for Developing Grounded Theory. 2nd ed., London: SAGE Publications.

Tung, V. W. S., \& Ritchie, J. R. B. (2011). Exploring the essence of memorable tourism experiences. Annals of Tourism Research, 38(4), 1367-1386.

Um, S., \& Crompton, L. (1990). Attitude determinants in tourism destination choice. Annals of Tourism Research, 17, 432-448.

Vazquez, R., Belen del Rio, A., \& Iglesias, V. (2002). Consumer-based brand equity: development and validation of a measurement instrument. Journal of Marketing Management, 18, 27-48.

Woodside, A. G., \& Lysonski, S. (1989). A General Model of Traveler Destination Choice. Journal of Travel Research, Spring, 8-14.

Yang, Y; Liu, X. \& Li, J (2015). How Customer Experience Affects the Customer-Based Brand Equity for Tourism Destinations. Journal of Travel \& Tourism Marketing, 32, 97-113.

Received: 28.07.2016

Revisions required: 10.08 .2016

Accepted: 18.10.2016 